\title{
Do Corporate Social Responsibility Campaighns Really Work: Cases in Turkey
}

\section{Assoc. Prof. Dr. Mesude Canan ÖZTÜRK, Anadolu Üniversitesi - TURKEY}

\begin{abstract}
Absract:
Improving a company's reputation and giving the public a positive impression are the main reasons for companies to take part in corporate social responsibility (CSR) activities. Corporations realized that social supports are becoming more important for continuity of their corporations. For this reason, the corporations have organized the activities beyond society and their needs. Within the context, corporate social responsibility activities have become more intensified in Turkey since 2000. Corporations are organizing social responsibility activities for publicity of their corporations as much as for social benefits. Therefore, it becomes more important to take a place in media with their social responsibility activities. In the present research, the awareness of CSR campaigns in Turkey is examined. The most popular five CSR campaigns, which were listed in Capital magazine in Turkey, will be discussed in the present study. The purpose of the study is to evaluate for recalling the company which owns the campaign, recalling the slogans, the feelings about the corporate reputation, the feelings about the campaign's success, and supporting the campaign. For this purpose, the questionnaire will be administered and analyzed to the university students.
\end{abstract}

Keywords: corporate social responsibility, social campaigns. 


\section{Introduction}

Corporate social responsibility (CSR) or corporate citizenship entails companies behaving in a socially responsible manner, and dealing with other business parties who do the same. With growing public awareness and demand for socially responsible businesses, it is little wonder that companies of today take corporate social responsibility into account when planning future socially responsible business operations.

"Through economic and historical developments that affect business and society as well as their interactions, the report starts with brief information about the country context of historical and economical developments. This section is followed by the demonstration of the actors and the interaction between them for creating and raising awareness on CSR in Turkey. Hence, these actors need a scenario and a platform to perform, this last section before the presentation of the research, describes the capacities of the CSR drives in the country. The report is finalized by suggestions for further capacity building and engagement of these actors for the enrichment of the CSR concept and implementation in Turkey.” (UNDP Report, 2008)

The question stated above has two meanings. The first meaning suggests that the communication attempts of corporations and organizations should be really effective. (Rogers, 1987). The next one suggests that the Project Works performed must increase the respect against corporations (Kadibesegil, 2006).

When we attempt to evaluate what aims are desired to achieve with the help of corporate responsibility campaign s, we can mention about three basic purposes here.

1- Achievement of the campaign $\mathrm{s}$ in reaching their aims.

2- Achievement of the communication attempts (raising awareness)

3- Contribution to corporations and organizations in gaining respect.

It is possible to learn about if campaign s have achieved their goal or not with the help of the web pages. Therefore, the scope of this study is to assess the communication activities performed to 
enable the campaign to achieve its goals and to assess the attitudes towards the corporate and organizations rather than the achievement of the campaign in reaching its goal.

Depending on this, this study researched for the awareness types related to communication techniques using communication attempts that corporations and organizations perform (Rogers, 1987). Therefore, recognition and reminding methods which are for measuring communication activities should follow communication practices (Basaran,2005). The fact that the projects increase the admiration of the corporations (Kadibesegil, 2006) is also examined in this study. Therefore, this study also investigates the perceptions related to the corporations and organizations.

There are a few specific reasons for the choice of this target crowd as the sampling of this study:

1- These students are also involved in the scope of the social campaign s as well.

2- This questionnaire will play a significant role in revealing the sensitiveness of the participants aged between 19 and 25 .

3- As those students are in the field of communication, their perceptions are quite high towards the commercials and commercial campaigns.

4- When these students finish their schools, they will be the candidates to plan and perform such social campaign s, they will report news for TVs and newspapers, and also they will make TV programmes.

If the examined corporations or organizations are successful or not with regards to the two perspectives suggested above is especially very significant for those students at Communication Faculty

If the examined corporations or organizations are successful or not with regards to the two perspectives suggested above is especially very significant for those students at Communication Faculty 
One of the most important reasons why the students from communication department were included in the sampling of the study is to get their attention regarding that they are expected to be aware of the communication studies carried out and these studies can create difference for the corporations and organizations

\section{The Awareness for Communication Studies}

It was necessary to adapt the recognition and reminding methods which are used to measure effectiveness of communication in social projects. This study does not simply relate to one advertisement. Many communication tools and promotion methods were used within the scope of the campaign s. Therefore, the recognition and recalling methods of the campaigns (with help or without help), were investigated with regards to recalling the advertising and communication works. It is very important for a corporation to remember the performer of a certain campaign. Recognition of campaign s and knowing about the corporations of these campaigns are the basic issues for corporate respect. Recalling the communication attempts related to the campaign demonstrates how successful it is. The corporations and organizations which aim to reach their target groups are expected to carry out effective communication attempts.

\section{Gaining Corporate Respect}

According to Kadıbeşegil, corporate reputation is the contribution margin within a market. It carries the abstract assets of a corporation. When we take it from this perspective, it appears that corporate reputation is considered among one of the most indispensable issues necessary for the continuity of corporations. Their criteria measuring to what extend social responsibility is fulfilled is among the corporate reputation criteria in general. This study also investigates if the participants would like to work for the corporations or not, if they support the corporations or not, if they consider that the corporation has positive images or not.

\section{Research Methods}

This study is based on a descriptive analysis carried out to reveal what kind of awareness social responsibility campaigns provoke on university students in Turkey and what their reactions are towards the corporations and organizations performing these campaign s. This study adapted a 
purposeful sampling method, and it was carried out on the students from the faculty of Communication, Anadolu University. Students from four different departments at the Faculty of Communication were chosen randomly from classes and then the questionnaire was administered to them.

The limitation of this study is that this questionnaire used in this study was submitted only to the students from Communication Faculty at Anadolu University. The questionnaire was administrated to the target students with the use of random sampling method for each of the four departments at this faculty.

Five different social responsibility works were chosen as the subject of the study. The choice for these campaigns was done considering the top five social responsibility projects of 2010 in public eye, which was published in March Volume of Capital Türkiye Magazine, 2010 (Bayıksel, 2010). The reason for this choice is that these projects with high admiration rates are expected to have higher public awareness and that if they have high admiration rates in students' eyes or not. (http://www.capital.com.tr/haber.aspx?HBR_KOD=5871)

What people need to know about these five campaign $\mathrm{s}$ is as follows:

1. Father, Send me to School (Baba Beni Okula Gönder)- BBOG Milliyet Newspaper and Association for Supporting Contemporary Life (Çağdaş Yaşamı Destekleme Derneği)

2. Lets Go to School, Girls (Haydi Kizlar Okula) - HKO

UNICEF ve Ministry of Education (MEB)

3. Stop Family Violence (Aile İçi Şiddet Son) - AISS Hurriyet Newspaper

4. Long Live Our School (Yasasin Okulumuz) - YO TOÇEV (Foundation for Educating Children ) and Show TV

5. Standing United for Education (Eğitimde Gönül Birliği) - EGB Arcelik 
Father, Send me to School (Baba Beni Okula Gönder)-Milliyet and Çağdaş Yaşamı Destekleme Derneği

The purpose of this campaign is to help those girls who had to leave their school for some reasons, such as family pressure or economical problems to continue their education. Significant majority of these students cannot attent schools either because there is no school in their neighbourhoods or there is not any boarding schools available nearby even their parents want them to attend school. These campaign s aim building boarding schools and providing financial supports for those girls. The campaign which was launched on 23 April 2005 has provided three year scholarship for 7.156 girls. It undertook the construction of 28 dormitaries, 10 primary schools were built and various educational and social activities were carried out. (http://www.bbog.org/index.html)

\section{Lets Go to School, Girls (Haydi Kızlar Okula) - UNICEF ve Ministry of Education (MEB)}

The purpose of this campaign which is led by MEB and UNICEF jointly, is to ensure \%100 enrollment of girls (aged between 6-14) who do not attend primary education, who had to leave their schools for some reasons or who do not attend their schools regularly, with the help of governmental organizations, non-governmental organizations and local governors. Thus, it aims to provide equal rights for girls and to remove sex discrimination in education. It was started in Van on 17 June 2003 with an agreement signed by the Ministery of Education and UNICEF. The investigations revealed that the number of girls who were not enrolled to any schools in Turkey was $273.447 .81 \%$ of them (222.800 girls) were helped to enroll school.

(http://haydikizlarokula.meb.gov.tr)

\section{Stop Family Violence (Aile İçi Şiddet Son)- Hurriyet Newspaper}

Hurriyet newspaper considered struggling against violence in the family as part of its social responsibility and launched the campaign, "Aile İçi Şiddete Son” in October, 2004. İstanbul Governorship and Çağdaş Eğitim Vakfı (ÇEV) were the two supporters of the campaign and then CNN Türk has become the third partner of the campaign . Aralık Derneği became the fourth partner of the campaign in 2008. (http://www.aileicisiddeteson.com//default.aspx) 


\section{Long Live Our School (Yasasın Okulumuz) - TOÇEV (Foundation for Educating Children) and Show TV}

An 'educational support' campaign. TOCEV runs this long-running campaign with SHOW TV and Ministry of National Education. With this 'LONG LIVE OUR SCHOOL' campaign which was brought to life in January 2005 they aim to repair 81 village primary schools in 81 cities, and to create new conditions for the students to forget how old-fashioned their schools are. By the year 2009, they repaired 200 village primary schools and made them shining bright in educational services." (http://www.tocev.org.tr/english.html)

\section{Standing United for Education (Eğitimde Gönül Birliği ) - Arcelik}

This campaign started on 22 March 2004 with the agreement signed by Arcelik A.S. and the Ministery of National Education. This social programme is carried out in 60 provinces and at 299 boarding schools with the help of Arcelik A.S. The purpose of this project is to focus on the personal developments of 200 students studying in these schools and to bring them up as modern individuals with great self confidence. (http://www.egitimdegonulbirligi.org/ust.aspx?uid=6)

To serve these purposes; the following research questions were addressed to this study;

a) What is the most preferred social issue for students in Turkey?

b) What are the corporations and organizations that they consider as being good social campaign performers?

c) Can students remember the corporations out of five social responsibility projects named?

d) Are the students aware of the aims of the five given social projects?

e) From which media means did they follow the advertisements of the five given social responsibility projects?

f) What are the students' attitudes towards the corporations and organizations which perform the named social responsibility projects?

The questionnaire which was prepared to come up with relevant answers to these questions contained the items related to demographic information primarily. For this purpose, the students 
were asked about their sexes, departments, classes, ages and their hometowns where their families live. Then, students were given a list of important social responsibility applications in Turkey and they were asked to rank three of them from 1 to 3 , considering the most important ones. Thus, it was aimed to reveal what issues have the highest priority for students in Turkey. The list of social responsibility projects contains those; education-health-environment- social development- culture and art-historical values- violence-economy-sport- aid to disabled peopleaid to autistics.

For the next step, students were asked to tell the names of the corporations and organization which most successfully perform corporate social responsibility projects in Turkey which they immediately recall when they are mentioned about social responsibility.

The following questions are about top five corporate social responsibility projects in public eye depending on the research conducted by Capital Turkey magazine. They were primarily given the names of the five projects and then asked to write about these projects as much as they remember. Considering the possibility that students cannot remember the names of those who supervise the campaigns, they were given a list of the names of ten corporations and organizations and then asked to choose five of them. To prevent students from writing their answers by going back to the previous section, they were warned to answer the questions without referring back to the previous sections. To evaluate if students had the relevant knowledge about the purpose of the campaign, students were asked to choose the purpose of the campaign from the given list in the next section.

17 items, which aim to evaluate what they remember about the advertisements, activities and speeches, were given in the next section and they were asked to choose one of the following options, such as "yes", "partially" and "no". In the final section, 15 items were given to the participants to evaluate their attitudes towards the corporations and organizations which perform the campaigns, and their answers were assessed using the "likert scale". The questionnaire was conducted in normal class hours under the supervision of the class lecturers in April 2010. The 
study was carried out using a quantitative research method. For the analysis of the data obtained, SPSS 11.5 program was used. With the help of this program, descriptive statistics was obtained.

\section{Results}

The questionnaire was administered to the students from four departments at the Faculty of Communication. The number of registered students at the faculty was 967 . The questionnaire was administrated to 300 students as the sampling. 261 of the collected questionnaire were considered valid for the study and they were evaluated. $46 \%$ of the 261 participants were female and $54 \%$ were male. The ages of the participants range between 19 and 26. The distribution of the participants depending on their departments is as follows (Table 01):

Table 01-Distribution of Departments

\begin{tabular}{|l|r|r|}
\hline \multicolumn{1}{|c|}{ Departments } & Frequency & \multicolumn{1}{|c|}{ Percent } \\
\hline Communication & 78 & 29,9 \\
Cinema \& Television & 53 & 20,3 \\
Journalism & 38 & 14,6 \\
PR \& Advertising & 92 & 35,2 \\
Total & 261 & 100,0 \\
\hline
\end{tabular}

$33.3 \%$ of the participants were class $1,23 \%$ of them were class $2,14,8 \%$ of them were class 3 , $28,7 \%$ of them were class 4 students.

In the questionnaire, the students were also asked to write the names of the cities where their families live. The answers obtained from the participants suggest that $14,5 \%$ of them live in Eskişehir, 44\% of them live in Ankara, Istanbul, Izmir, Bursa and Antalya. Only 3 of the families live abroad.

\section{General considerations about corporate social responsibility projects}

The participants of the study were asked to rank the significant social responsibility practices in Turkey, from 1 to 3 considering their significance. When we examine the responses received, education, health and violence are placed in the top 3 rank considering how many times they had a rank without taking their significance degree into consideration (Table 02). Education is the 
first rank which is considered to be the most significant one. Aid to autistics is the one which is considered to be the least significant one out of them.

The issues resulted from global warming are seen as primary issues throughout the world, especially in Europe and America. According to the responses of the participants, the significance degree of environmental issues comes after economical issues, at the 5th rank.

Table 02 Distribution of social problems

\begin{tabular}{|c|c|c|c|c|c|c|}
\hline & education & health & environment & social prg. & culture/art & historical vl. \\
\hline Number 1 & $\mathbf{1 4 0}$ & 25 & 3 & 10 & 2 & 0 \\
\hline Number 2 & 39 & 44 & 17 & 20 & 9 & 4 \\
\hline Number 3 & 15 & 37 & 25 & 31 & 6 & 13 \\
\hline Total & $\mathbf{1 9 4}$ & $\mathbf{1 0 6}$ & 45 & 61 & 17 & 17 \\
\hline
\end{tabular}

\begin{tabular}{|c|c|c|c|c|c|c|}
\hline & violance & economy & Sport & disabled & otism & other \\
\hline Number 1 & 11 & 6 & 4 & 9 & 0 & 0 \\
\hline Number 2 & 35 & 20 & 4 & 13 & 4 & 1 \\
\hline Number 3 & 23 & 29 & 8 & 18 & 2 & 3 \\
\hline Total & $\mathbf{6 9}$ & 55 & 16 & 40 & $\mathbf{6}$ & 4 \\
\hline
\end{tabular}

The findings obtained from the participants suggest that the most successfully performed social responsibility campaigns in Turkey are mostly those related to helping girls' education (Table $03)$.

Table 03- Distribution of Succesfull Campaigns

\begin{tabular}{lrr}
\hline Campaigns & Frequency & Percent \\
\hline Baba Beni Okula Gönder (BBOG) & 90 & 45,9 \\
Dumansiz Hava Sahası & 6 & 3,1 \\
Haydi Kizlar Okula (HKO) & 54 & 27,6 \\
Kardelenler & 33 & 16,8 \\
Other & 13 & 6,6 \\
& 196 & 100,0 \\
\hline
\end{tabular}

The responses of the students included in the questionnaire suggest that when they are asked about social responsibility, they write the corporations and organizations which support the education at most. Among the ones considered to be successful, ACEV, CYDD, TEGV, TEV are the non-governmental organizations contributing to education, TEMA is a charitable foundation in the field of environmental protection and forestation. Milliyet (newspaper) and Turkcell (GSM operator) are the commercial corporations known as contributing to education. In the list, 
MEB ( the Ministry of National Education) is the only governmental organization and UNICEF is the only international organization (Table 04).

\begin{tabular}{lrr}
\multicolumn{3}{c}{ Table 04 - Distribution of Succesfull Companies } \\
\hline Companies & Frequency & Percent \\
\hline ACEV & 6 & 3,2 \\
CYDD & 19 & 10,1 \\
TEGV & 35 & 18,5 \\
TEMA & 21 & 11,1 \\
Milliyet & 5 & 2,6 \\
Turkcell & 48 & 25,4 \\
UNICEF & 7 & 3,7 \\
TEV & 12 & 6,3 \\
MEB & 11 & 5,8 \\
Other & 25 & 13,2 \\
Total & 189 & 100,0 \\
\hline
\end{tabular}

\section{The evaluation of the thoughts about five projects}

When the students were asked to write about the performers of the top five campaigns as much as they can remember, "Baba Beni Okula Gönder" Campaign was found to be the most accurately remembered one which was performed by Milliyet Newspaper (Table 05). "Yaşasın Okulumuz" which is performed by Show TV comes next. "Haydi Kizlar Okula" which was launched jointly by MEB and UNICEF and currently performed by MEB single handedly comes in the third rank. This campaign was also found to be the most error prone one to be misspelled.

Table 05 Distribution of Campaigns' Organizers

\begin{tabular}{|l|r|r|r|r|r|r|r|r|r|r|}
\hline \multirow{4}{*}{} & \multicolumn{2}{|c|}{ bbog } & \multicolumn{2}{|c|}{ hko } & \multicolumn{2}{|c|}{ aiss } & \multicolumn{2}{|c|}{ yo } & \multicolumn{2}{|c|}{ egb } \\
\cline { 2 - 10 } & Freq. & \multicolumn{1}{c|}{$\%$} & Freq. & \multicolumn{1}{c|}{$\%$} & Freq. & \% & Freq. & $\%$ & Freq. & \multicolumn{1}{c}{$\%$} \\
\cline { 2 - 11 } unanswered & 146 & 55,9 & 150 & 57,5 & 243 & 93,1 & 205 & 78,5 & 232 & 88,9 \\
correct & $\mathbf{4 2}$ & 16,1 & $\mathbf{1 6}$ & 6,1 & 6 & 2,3 & $\mathbf{3 0}$ & 11,5 & 1 & 0,4 \\
incorrect & 73 & 28 & $\mathbf{9 5}$ & 36,4 & 12 & 4,6 & 26 & 10 & 28 & 10,7 \\
total & $\mathbf{2 6 1}$ & $\mathbf{1 0 0}$ & $\mathbf{2 6 1}$ & $\mathbf{1 0 0}$ & $\mathbf{2 6 1}$ & $\mathbf{1 0 0}$ & $\mathbf{2 6 1}$ & $\mathbf{1 0 0}$ & $\mathbf{2 6 1}$ & $\mathbf{1 0 0}$ \\
\hline
\end{tabular}

Considering that students could remember the performers of the campaigns directly, they were given ten names of campaign performers in the following step and then they were requested to 
pick one name for a certain campaign as the performer from the given list of names. The results obtained are as follows:(Table 06):

Table 06 Distribution of The Lists of Campaigns' Organizers

\begin{tabular}{|l|r|r|r|r|r|r|r|r|r|r|}
\hline \multirow{4}{*}{} & \multicolumn{2}{|c|}{ bbog } & \multicolumn{2}{c|}{ hko } & \multicolumn{2}{c|}{ aiss } & \multicolumn{2}{|c|}{ yo } & \multicolumn{2}{|c|}{ egb } \\
\cline { 2 - 10 } & Freq. & \multicolumn{1}{c|}{$\%$} & Freq. & \multicolumn{1}{c|}{$\%$} & Freq. & \multicolumn{1}{c|}{$\%$} & Freq. & $\%$ & Freq. & \multicolumn{1}{c}{$\%$} \\
\cline { 2 - 10 } unanswered & 33 & 12,6 & 32 & 12,3 & 61 & 23,4 & 49 & 18,8 & 62 & 23,8 \\
correct & 50 & $\mathbf{1 9 , 2}$ & 32 & $\mathbf{1 2 , 3}$ & 23 & 8,8 & 46 & $\mathbf{1 7 , 6}$ & 3 & 1,1 \\
incorrect & 129 & $\mathbf{4 9 , 4}$ & 149 & $\mathbf{5 7 , 1}$ & 34 & 13,0 & 66 & 25,3 & 86 & 33,0 \\
unknown & 49 & 18,8 & 48 & 18,4 & 143 & $\mathbf{5 4 , 8}$ & 100 & 38,3 & 110 & $\mathbf{4 2 , 1}$ \\
total & 261 & 100,0 & 261 & 100,0 & 261 & 100,0 & 261 & 100,0 & 261 & 100,0 \\
\hline
\end{tabular}

"Baba Beni Okula Gönder" by Milliyet Newspaper was found to have matched most accurately with the correct name by $19.2 \%$. (Table 6). Then comes "Yaşasın Okulumuz" by Show TV by $17.6 \%$ and "Haydi Kizlar Okula" by MEB-UNICEF comes next by $12.7 \%$.

The list was given to the students just to help them remember and they were asked to choose the "Bilmiyorum" option if they really did not know who the performer of that campaign was rather than trying to guess. The campaign s that the students claimed to be unaware most were "Aile İçi Şiddete son” (54.8\%) and "'Eğitimde Gönül Birliği (42.1\%) (Table 6 ).

It was also found that students largely failed in their choices when they had guesses thinking that they knew the answer. The campaigns which were matched most correctly were also those which failed at most (Table 6). The rate of those who failed to list the performer of "Baba Beni Okula Gönder" campaign is higher that those who listed correctly $(\% 49,4)$ and the rate for those who failed to list the performer of "Haydi Kizlar Okula" campaign correctly was found to be $\% 57,1$.

This reality suggests that students' awareness related to these two campaigns is high and that they consider they remember their performers correctly. However, it is clear that the fact that many different campaigns are organized for similar purposes leads to confusion in people's minds, such as which campaigns are organized by whom. 
A list of 10 objective lists was prepared so that students could assess the purposes of certain campaigns and students were requested to choose one out of them. The following findings were obtained: (Table 07):

Table 07 Distribution of The List of Campaigns' Goals

\begin{tabular}{|l|r|r|r|r|r|r|r|r|r|r|}
\hline & \multicolumn{2}{|c|}{ bbog } & \multicolumn{2}{c|}{ hko } & \multicolumn{2}{|c|}{ aiss } & \multicolumn{2}{|c|}{ yo } & \multicolumn{2}{|c|}{ egb } \\
\cline { 2 - 10 } & Freq. & \multicolumn{1}{c|}{$\%$} & Freq. & \% & Freq. & \% & Freq. & $\%$ & Freq. & $\%$ \\
\cline { 2 - 10 } unanswered & 23 & 8,8 & 14 & 5,4 & 21 & 8,0 & 21 & 8,0 & 36 & 13,8 \\
correct & 190 & 72,8 & 229 & 87,7 & 222 & 85,1 & 86 & 33,0 & 26 & 10,0 \\
incorrect & 26 & 10,0 & 7 & 2,7 & 6 & 2,3 & 133 & $\mathbf{5 1 , 0}$ & 106 & $\mathbf{4 0 , 6}$ \\
unknown & 22 & 8,4 & 11 & 4,2 & 12 & 4,6 & 21 & 8,0 & 93 & 35,6 \\
total & 261 & 100,0 & 261 & 100,0 & 261 & 100,0 & 261 & 100,0 & 261 & 100,0 \\
\hline
\end{tabular}

As they were choosing the relevant purposes from the list of campaigns, the accuracy rate was found to be $87,7 \%$ (Haydi Kizlar Okula) (Table 07).

The most erroneous choice was found to be 51\% (Yaşasın Okulumuz Campaign ) and the campaign which was the least known was "Eğitimde Gönül Birliği" (35,6\%). The names of the campaigns include the objectives of the campaigns, which may have a positive effect on recalling the names of the campaigns. 17 statements related to the recall of the advertisement and activity works of the campaigns were assessed with the following options; "yes, partially and no".

1. I remember the campaign

2. I remember it if I see the logo of the campaign.

3. I do not remember the activities of the campaign.

4. I participated in the activities of the campaign.

5. I contributed to the campaign (through Money or volunteer working)

6. I remember the TV commercial of the campaign.

7. I remember the newspaper advertisement of the campaign.

8. I remember the magazine advertisement of the campaign.

9. I remember the Internet advertisement of the campaign.

10. I remember the radio spot of the campaign. 
11. I remember the TV program about the campaign.

12. I remember the TV news about the campaign.

13. I remember reading a column about the campaign.

14. I remember reading a news text about the campaign.

15. I remember a magazine article about the campaign.

16. I remember people talking about the campaign.

17. I remember visiting the web pages of the campaign.

The rates of the answers received from the students are as follows: (Table 08):

The rates of those who suggest that they remember the campaign, "Baba Beni Okula Gönder" (72.5\%), its logo (74.4\%) and it TV commercial (72.3\%) are quite high (Table 08). Besides, the rate of those who suggest that they have heard people talking about the campaign is also quite high $(73,1 \%)$. The rate of those who suggest that they did not participate in any activity related to the campaign (90.3\%), that they did not contribute to it(79\%) is also quite high. Similarly, the rate of those who suggest that they did not remember the radio spot related to the campaign $(70.5 \%)$ and magazine article $(76.8 \%)$ are quite high.

Table 08 Distribution of Remembering the Levels of Campaigns' Promotions Applications

\begin{tabular}{|c|c|c|c|c|c|c|c|c|c|}
\hline \multicolumn{2}{|r|}{ Father, Send me to School (Baba Beni Okula Gönder)- BBOG } & \multicolumn{2}{|c|}{$\overline{\text { Yes }}$} & \multicolumn{2}{|c|}{ Partly } & \multicolumn{2}{|c|}{ No } & \multicolumn{2}{|c|}{ Total } \\
\hline & & Fre. & $\%$ & Fre. & $\%$ & Fre. & $\%$ & Fre. & $\%$ \\
\hline 1 & I remember the campaign & 187 & 72,5 & 62 & 24,0 & 9 & 3,5 & 258 & 100,0 \\
\hline 2 & I remember it if I see the logo of the campaign. & 189 & 74,4 & 41 & 16,1 & 24 & 9,4 & 254 & 100,0 \\
\hline 3 & I do not remember the activities of the campaign. & 103 & 40,9 & 104 & 41,3 & 45 & 17,9 & 252 & 100,0 \\
\hline 4 & I participated in the activities of the campaign . & 6 & 2,4 & 18 & 7,3 & 224 & 90,3 & 248 & 100,0 \\
\hline 5 & I contributed to the campaign (through Money or volunteer working) & 32 & 12,7 & 21 & 8,3 & 199 & 79,0 & 252 & 100,0 \\
\hline 6 & I remember the TV commercial of the campaign . & 185 & 72,3 & 58 & 22,7 & 13 & 5,1 & 256 & 100,0 \\
\hline 7 & I remember the newspaper advertisement of the campaign . & 111 & 44,0 & 77 & 30,6 & 64 & 25,4 & 252 & 100,0 \\
\hline 8 & I remember the magazine advertisement of the campaign & 56 & 21,9 & 51 & 19,9 & 149 & 58,2 & 256 & 100,0 \\
\hline 9 & I remember the Internet advertisement of the campaign. & 78 & 30,6 & 57 & 22,4 & 120 & 47,1 & 255 & 100,0 \\
\hline 10 & I remember the radio spot of the campaign. & 36 & 14,3 & 38 & 15,1 & 177 & 70,5 & 251 & 100,0 \\
\hline
\end{tabular}




\begin{tabular}{|c|c|c|c|c|c|c|c|c|c|}
\hline 11 & I remember the TV programme about the campaign . & 117 & 47,0 & 71 & 28,5 & 61 & 24,5 & 249 & 100,0 \\
\hline 12 & I remember the TV news about the campaign. & 95 & 38,2 & 77 & 30,9 & 77 & 30,9 & 249 & 100,0 \\
\hline 13 & I remember reading a column about the campaign . & 55 & 22,0 & 50 & 20,0 & 145 & 58,0 & 250 & 100,0 \\
\hline 14 & I remember reading a news text about the campaign . & 100 & 39,5 & 64 & 25,3 & 89 & 35,2 & 253 & 100,0 \\
\hline 15 & I remember a magazine article about the campaign . & 26 & 10,2 & 33 & 13,0 & 195 & 76,8 & 254 & 100,0 \\
\hline 16 & I remember people talking about the campaign . & 182 & 73,1 & 45 & 18,1 & 22 & 8,8 & 249 & 100,0 \\
\hline 17 & I remember visiting the web pages of the campaign. & 46 & 18,3 & 35 & 13,9 & 171 & 67,9 & 252 & 100,0 \\
\hline
\end{tabular}

The rates of those who suggest that they remember "Haydi Kizlar Okula" Campaign (69.3\%) and its logo (61.8\%) and its TV commercial (66.2\%) are quite high (Table 09). In addition to these, the rate of those who suggest that they remember people talking about the campaign is also very high again $(\% 70,1)$. The rate of those who suggest that they did not participate in any activity related to the campaign $(88,2 \%)$, that they did not contribute to it $(75.7 \%)$ are quite high. Similarly, the rates of those who suggest that they did not remember the radio spot related to the campaign (72\%), magazine article (76.8\%) and that they did not visit the web page of the campaign $(69.2 \%)$ are also quite high.

Table 09 - Distribution of Remembering the Levels of Campaigns' Promotions Applications

\begin{tabular}{|c|c|c|c|c|c|c|c|c|c|}
\hline \multicolumn{2}{|r|}{ Lets Go to School, Girls (Haydi Kızlar Okula) - HKO } & \multicolumn{2}{|c|}{ Yes } & \multicolumn{2}{|c|}{ Partly } & \multicolumn{2}{|c|}{ No } & \multicolumn{2}{|c|}{ Total } \\
\hline & & Fre. & $\%$ & Fre. & $\%$ & Fre. & $\%$ & Fre. & $\%$ \\
\hline 1 & I remember the campaign & 169 & 69,3 & 66 & 27,0 & 9 & 3,7 & 244 & 100,0 \\
\hline 2 & I remember it if I see the logo of the campaign . & 149 & 61,8 & 68 & 28,2 & 24 & 10,0 & 241 & 100,0 \\
\hline 3 & I do not remember the activities of the campaign & 101 & 41,7 & 96 & 39,7 & 45 & 18,6 & 242 & 100,0 \\
\hline 4 & I participated in the activities of the campaign . & 7 & 2,8 & 23 & 9,1 & 224 & 88,2 & 254 & 100,0 \\
\hline 5 & I contributed to the campaign & 36 & 13,7 & 28 & 10,6 & 199 & $\mathbf{7 5 , 7}$ & 263 & 100,0 \\
\hline 6 & I remember the TV commercial of the campaign . & 153 & 66,2 & 65 & 28,1 & 13 & 5,6 & 231 & 100,0 \\
\hline 7 & I remember the newspaper advertisement.f the campaign . & 89 & 37,7 & 83 & 35,2 & 64 & 27,1 & 236 & 100,0 \\
\hline 8 & I remember the magazine advertisement of the campaign & 48 & 19,5 & 49 & 19,9 & 149 & 60,6 & 246 & 100,0 \\
\hline 9 & I remember the Internet advertisement of the campaign . & 77 & 31,2 & 50 & 20,2 & 120 & 48,6 & 247 & 100,0 \\
\hline
\end{tabular}




\begin{tabular}{|l|l|r|r|r|r|r|r|r|r|}
$\mathbf{1 0}$ & I remember the radio spot of the campaign . & 29 & 11,8 & 40 & 16,3 & 177 & $\mathbf{7 2 , 0}$ & 246 & 100,0 \\
\hline $\mathbf{1 1}$ & I remember the TV programme about the campaign & 108 & 46,2 & 65 & 27,8 & 61 & 26,1 & 234 & 100,0 \\
\hline $\mathbf{1 2}$ & I remember the TV news about the campaign . & 92 & 38,3 & 71 & 29,6 & 77 & 32,1 & 240 & 100,0 \\
\hline $\mathbf{1 3}$ & I remember reading a column about the campaign & 52 & 21,1 & 50 & 20,2 & 145 & 58,7 & 247 & 100,0 \\
\hline $\mathbf{1 4}$ & I remember reading a news text about the campaign & 94 & 39,7 & 54 & 22,8 & 89 & 37,6 & 237 & 100,0 \\
\hline $\mathbf{1 5}$ & I remember a magazine article about the campaign. & 24 & 9,4 & 35 & 13,8 & 195 & $\mathbf{7 6 , 8}$ & 254 & 100,0 \\
\hline $\mathbf{1 6}$ & I remember people talking about the campaign . & 162 & $\mathbf{7 0 , 1}$ & 47 & 20,3 & 22 & 9,5 & 231 & 100,0 \\
\hline $\mathbf{1 7}$ & I remember visiting the web pages of the campaign . & 43 & 17,4 & 33 & 13,4 & 171 & $\mathbf{6 9 , 2}$ & 247 & 100,0 \\
\hline
\end{tabular}

The rates of those who suggest that they remember the campaign , "Aile İçi Şiddete Son" (27.3\%), its logo (25.3\%) and its TV commercial (27.4\%) are quite high compared to the rates of the other statements, but they are low in general (Table 10). Besides, whereas the rate of those who suggest that they remember people talking about the campaign is quite low, it appears to be the highest compared to those of the other statements $(\% 37,8)$. The rates of those who suggest that they did not participate in any activities related to the campaign $(92,9 \%)$, that they did not contribute to the campaign $(89,9 \%)$ are quite high. The rates of those who suggest that they did not remember the magazine advertisements related to the campaign (77,9\%), the radio spot (72\%), that they did not read any column $(75,8 \%)$ that they did not remember any magazine articles $(83,1 \%)$ and that they did not visit their web pages $(82,5 \%)$ are quite high.

Table 10 Distribution of Remembering the Levels of Campaigns' Promotions Applications

\begin{tabular}{|c|c|c|c|c|c|c|c|c|c|}
\hline \multicolumn{2}{|r|}{ Stop Family Violence (Aile İçi Şiddet Son)-AISS } & \multicolumn{2}{|c|}{ Yes } & \multicolumn{2}{|c|}{ Partly } & \multicolumn{2}{|c|}{ No } & \multicolumn{2}{|c|}{ Total } \\
\hline & & Fre. & $\%$ & Fre. & $\%$ & Fre. & $\%$ & Fre. & $\%$ \\
\hline 1 & I remember the campaign & 66 & 27,3 & 81 & 33,5 & 95 & 39,3 & 242 & 100,0 \\
\hline 2 & I remember it if I see the logo of the campaign. & 62 & 25,3 & 64 & 26,1 & 119 & 48,6 & 245 & 100,0 \\
\hline 3 & I do not remember the activities of the campaign & 24 & 10,2 & 75 & 31,9 & 136 & 57,9 & 235 & 100,0 \\
\hline 4 & I participated in the activities of the campaign . & 4 & 1,7 & 13 & 5,5 & 221 & $\mathbf{9 2 , 9}$ & 238 & 100,0 \\
\hline 5 & I contributed to the campaign (through Money or volunteer working) & 11 & 4,6 & 13 & 5,5 & 214 & 89,9 & 238 & 100,0 \\
\hline 6 & I remember the TV commercial of the campaign & 65 & 27,4 & 67 & 28,3 & 105 & 44,3 & 237 & 100,0 \\
\hline 7 & I remember the newspaper advertisement of the campaign & 31 & 13,1 & 61 & 25,7 & 145 & 61,2 & 237 & 100,0 \\
\hline
\end{tabular}




\begin{tabular}{|c|c|c|c|c|c|c|c|c|c|}
\hline 8 & I remember the magazine advertisement of the campaign & 17 & 7,1 & 36 & 15,0 & 187 & 77,9 & 240 & 100,0 \\
\hline 9 & I remember the Internet advertisement of the campaign . & 25 & 10,4 & 57 & 23,8 & 158 & 65,8 & 240 & 100,0 \\
\hline 10 & I remember the radio spot of the campaign . & 10 & 4,2 & 27 & 11,3 & 201 & 84,5 & 238 & 100,0 \\
\hline 11 & I remember the TV programme about the campaign . & 29 & 12,3 & 58 & 24,7 & 148 & 63,0 & 235 & 100,0 \\
\hline 12 & I remember the TV news about the campaign . & 39 & 16,9 & 53 & 22,9 & 139 & 60,2 & 231 & 100,0 \\
\hline 13 & I remember reading a column about the campaign & 22 & 9,2 & 36 & 15,0 & 182 & 75,8 & 240 & 100,0 \\
\hline 14 & I remember reading a news text about the campaign . & 36 & 15,1 & 49 & 20,6 & 153 & 64,3 & 238 & 100,0 \\
\hline 15 & I remember a magazine article about the campaign . & 11 & 4,6 & 29 & 12,2 & 197 & 83,1 & 237 & 100,0 \\
\hline 16 & I remember people talking about the campaign . & 91 & $\mathbf{3 7 , 8}$ & 50 & 20,7 & 100 & 41,5 & 241 & 100,0 \\
\hline 17 & I remember visiting the web pages of the campaign . & 22 & 9,2 & 20 & 8,3 & 198 & 82,5 & 240 & 100,0 \\
\hline
\end{tabular}

The rates of those who suggest that they remember the campaign , "Yaşasın Okulumuz" (40\%), its logo (34.2\%) and its TV commercials (37.1\%) and its TV program (32.7\%) are slightly lower that the average (Table 11). Besides, the rate of those who suggest that they remember people talking about the campaign appears to be on the average $(\% 44,7)$. The rate of those who suggest that they did not participate in any activities related to the campaign $(88,4 \%)$, that they did not contribute to the campaign $(82 \%)$ is quite high. Similarly, the rate of those who suggest that they did not remember the magazine advertisement related to the campaign $(75,1 \%)$ its radio spot $(80,3 \%)$, that they did not read any column $(73,8 \%)$, that they did not remember any magazine articles.

Table 11 Distribution of Remembering the Levels of Campaigns' Promotions Applications

\begin{tabular}{|c|c|c|c|c|c|c|c|c|c|}
\hline & \multirow[t]{2}{*}{ Long Live Our School (Yasasın Okulumuz) - YO } & \multicolumn{2}{|c|}{ Yes } & \multicolumn{2}{|c|}{ Partly } & \multicolumn{2}{|c|}{ No } & \multicolumn{2}{|c|}{ Total } \\
\hline & & Fre. & $\%$ & Fre. & $\%$ & Fre. & $\%$ & Fre. & $\%$ \\
\hline 1 & I remember the campaign & 98 & 40,0 & 96 & 39,2 & 51 & 20,8 & 245 & 100,0 \\
\hline 2 & I remember it if I see the logo of the campaign . & 83 & $\mid 34,2$ & 71 & 29,2 & 89 & 36,6 & 243 & 100,0 \\
\hline 3 & I do not remember the activities of the campaign & 60 & 25,1 & 79 & 33,1 & 100 & 41,8 & 239 & 100,0 \\
\hline 4 & I participated in the activities of the campaign & 6 & 2,5 & 22 & 9,1 & 214 & 88,4 & 242 & 100,0 \\
\hline 5 & I contributed to the campaign & 19 & 7,8 & 25 & 10,2 & 200 & 82,0 & 244 & 100,0 \\
\hline 6 & I remember the TV commercial of the campaign . & 92 & \begin{tabular}{|l|}
37,1 \\
\end{tabular} & 72 & 29,0 & 84 & 33,9 & 248 & 100,0 \\
\hline 7 & I remember the newspaper advertisement of the campaign & 44 & 18,0 & 65 & 26,6 & 135 & 55,3 & 244 & 100,0 \\
\hline
\end{tabular}




\begin{tabular}{|c|c|c|c|c|c|c|c|c|c|}
\hline 8 & I remember the magazine advertisement of the campaign & 26 & 10,6 & 35 & 14,3 & 184 & 75,1 & 245 & 100,0 \\
\hline 9 & I remember the Internet advertisement of the campaign & 42 & 17,0 & 50 & 20,2 & 155 & 62,8 & 247 & 100,0 \\
\hline 10 & I remember the radio spot of the campaign. & 19 & 7,8 & 29 & 11,9 & 196 & 80,3 & 244 & 100,0 \\
\hline 11 & I remember the TV programme about the campaign . & 80 & 32,7 & 46 & 18,8 & 119 & 48,6 & 245 & 100,0 \\
\hline 12 & I remember the TV news about the campaign & 62 & 25,5 & 60 & 24,7 & 121 & 49,8 & 243 & 100,0 \\
\hline 13 & I remember reading a column about the campaign . & 28 & 11,5 & 36 & 14,8 & 180 & 73,8 & 244 & 100,0 \\
\hline 14 & I remember reading a news text about the campaign . & 47 & 19,3 & 47 & 19,3 & 150 & 61,5 & 244 & 100,0 \\
\hline 15 & I remember a magazine article about the campaign . & 16 & 6,5 & 33 & 13,5 & 196 & 80,0 & 245 & 100,0 \\
\hline 16 & I remember people talking about the campaign . & 110 & 44,7 & 55 & 22,4 & 81 & 32,9 & 246 & 100,0 \\
\hline 17 & I remember visiting the web pages of the campaign. & 23 & 9,3 & 27 & 10,9 & 197 & \begin{tabular}{|l}
79,8 \\
\end{tabular} & 247 & 100,0 \\
\hline
\end{tabular}

The rate of those participants who suggest that they remember the campaign , "Eğitimde Gönül Birliği” (13.2\%), its logo (13.1\%) is quite low (Table 12). Similarly, the rate of those who remember people talking about the campaign appears to be the highest compared to the others $(\% 18,1)$. The rate of those participants who suggest that they did not participate in the activities related to the campaign $(92,9 \%)$, that they did not contribute to the campaign $(90,2 \%)$ is quite high. Likewise, the rate of those who suggest that they did not remember the radio spot related to the campaign $(91,4 \%)$, that they did not read any column $(73,8 \%)$, that they did not remember reading any magazine article $(89,8 \%)$ and that they did not visit any web pages of the campaign $(90,3 \%)$ are quite high.

Table 12 Distribution of Remembering the Levels of Campaigns' Promotions Applications

\begin{tabular}{|c|c|c|c|c|c|c|c|c|c|}
\hline \multicolumn{2}{|r|}{$\begin{array}{l}\text { Standing United for Education (Ĕgitimde Gönül } \\
\text { Birliği) - EGB }\end{array}$} & \multicolumn{2}{|c|}{ Yes } & \multicolumn{2}{|c|}{ Partly } & \multicolumn{2}{|c|}{ No } & \multicolumn{2}{|c|}{ Total } \\
\hline & & Fre. & $\%$ & Fre. & $\%$ & Fre. & $\%$ & Fre. & $\%$ \\
\hline 1 & I remember the campaign & 32 & 13,2 & 56 & 23,0 & 155 & 63,8 & 243 & 100,0 \\
\hline 2 & I remember it if I see the logo of the campaign . & 32 & 13,1 & 45 & 18,4 & 168 & 68,6 & 245 & 100,0 \\
\hline 3 & I do not remember the activities of the campaign & 13 & 5,5 & 45 & 19,0 & 179 & 75,5 & 237 & 100,0 \\
\hline 4 & I participated in the activities of the campaign & 7 & 2,9 & 10 & 4,1 & 224 & 92,9 & 241 & 100,0 \\
\hline 5 & $\begin{array}{l}\text { I contributed to the campaign (through Money or volunteer } \\
\text { working) }\end{array}$ & 6 & 2,5 & 18 & 7,4 & 220 & 90,2 & 244 & 100,0 \\
\hline
\end{tabular}




\begin{tabular}{|c|c|c|c|c|c|c|c|c|c|}
\hline 6 & I remember the TV commercial of the campaign . & 25 & 10,2 & 40 & 16,3 & 181 & 73,6 & 246 & 100,0 \\
\hline 7 & I remember the newspaper advertisement of the campaign . & 17 & 7,1 & 30 & 12,5 & 193 & 80,4 & 240 & 100,0 \\
\hline 8 & I remember the magazine advertisement of the campaign & 11 & 4,5 & 23 & 9,4 & 210 & 86,1 & 244 & 100,0 \\
\hline 9 & I remember the Internet advertisement of the campaign . & 13 & 5,3 & 30 & 12,3 & 201 & 82,4 & 244 & 100,0 \\
\hline 10 & I remember the radio spot of the campaign. & 8 & 3,3 & 13 & 5,3 & 223 & 91,4 & 244 & 100,0 \\
\hline 11 & I remember the TV programme about the campaign. & 17 & 7,0 & 33 & 13,5 & 194 & 79,5 & 244 & 100,0 \\
\hline 12 & I remember the TV news about the campaign. & 28 & 11,6 & 35 & 14,5 & 178 & 73,9 & 241 & 100,0 \\
\hline 13 & I remember reading a column about the campaign . & 13 & 5,3 & 19 & 7,8 & 211 & 86,8 & 243 & 100,0 \\
\hline 14 & I remember reading a news text about the campaign . & 21 & 8,6 & 32 & 13,1 & 191 & 78,3 & 244 & 100,0 \\
\hline 15 & I remember a magazine article about the campaign . & 7 & 2,9 & 18 & 7,3 & 220 & 89,8 & 245 & 100,0 \\
\hline 16 & I remember people talking about the campaign . & 45 & 18,1 & 43 & 17,3 & 160 & 64,5 & 248 & 100,0 \\
\hline 17 & I remember visiting the web pages of the campaign . & 12 & 4,9 & 12 & 4,9 & 223 & 90,3 & 247 & 100,0 \\
\hline
\end{tabular}

When we examine the results, especially the recall rates for the first two campaigns are found to be quite high. This is very significant as it reflects people's likes. The fact that TV commercials are placed among those which are remembered at most reveals that the most commonly used media of the participants is TV. In the following section, students were asked if they really remember an advertisement or not and those who remember were asked to state it in one single sentence.

The participants are provided with the following options to assess the attitudes of the participants towards the corporates and organizations performing the campaign ; "I strongly disagree", "I disagree", "neutral", "I agree" and "I strongly agree". The statements questioning the participants' opinions are as follows:

1. I consider that the campaign is very beneficial to the society.

2. I consider that the compaing is of great success.

3. I appreciate the performer for this campaign.

4. I want to contribute to this campaign through volunteery work.

5. I consider that the campaign is dealt with sufficiently

6. I consider that the subject of the campaign is relevant to the field of the corporate. 
7. I consider that the corporate serves the purpose of the campaign.

8. I consider that the communication tools are effectively and sufficiently used in the campaign.

9. I consider that the society is sufficiently informed about the campaign.

10. I consider that the compaing works in a way to increase the respect of the corporate in public eye.

11. I consider that the campaign contribute to the positive image of the corporate.

12. I consider that the corporate behaves ethically in the campaign related works.

13. I consider that the corporate should continue its campaign related activities

14. I appreciate the corporate for its attempts in social responsibilities.

15. The social responsibility attempts of the corporate are affective in my decision making processes to buy.

The statements that the participants suggest that they strongly agree with are as follows: (Table 13):

The rate of those who suggest that they agree and strongly agree with the statement, "I consider that the campaign is beneficial to the society" is $90 \%$.

The rate of those who suggest that they agree and strongly agree with the statement, "I consider that the campaign helps the corporate gain more respect" is $74 \%$.

The rate of those who suggest that they agree and strongly agree with the statement, "I consider that the campaign contributes to the corporate in making positive image" is $79.7 \%$.

The statements that the participants suggest that they strongly disagree with are as follows.

The rate of those who suggest that they agree and strongly agree with the statement, "I would wish to work for this campaign as well" is $14.3 \%$.

The rate of those who suggest that they agree and strongly agree with the statement, "the social responsibility attempts of the corporate are affective in my decision making processes to buy" is $16.4 \%$.

The highest neutral rate is for the following statement "I consider that the corporate behaves ethically in its campaign related activities $(\% 43,3)$. 
Table 13 Distribution of Opinion About The Campaigns

\begin{tabular}{|c|c|c|c|c|c|c|c|c|c|c|c|c|c|}
\hline \multicolumn{2}{|r|}{ Father, Send me to School(Baba Beni Okula Gönder)- BBOG } & \multicolumn{2}{|c|}{$\begin{array}{l}\text { Strongly } \\
\text { Disagree }\end{array}$} & \multicolumn{2}{|c|}{ Disagree } & \multicolumn{2}{|c|}{ Neutral } & \multicolumn{2}{|c|}{ Agree } & \multicolumn{2}{|c|}{$\begin{array}{l}\text { Strongly } \\
\text { Agree }\end{array}$} & \multicolumn{2}{|c|}{ Total } \\
\hline & & Fre. & $\%$ & Fre. & $\%$ & Fre. & $\%$ & Fre. & $\%$ & Fre. & $\%$ & Fre. & $\%$ \\
\hline 1 & $\begin{array}{l}\text { I consider that the campaign is very beneficial to the } \\
\text { society. }\end{array}$ & 2 & 0,8 & 10 & 3,9 & 16 & 6,2 & 108 & 41,7 & 123 & 47,5 & 259 & 100,0 \\
\hline 2 & I consider that the campaing is of great success. & 3 & 1,2 & 10 & 3,9 & 54 & 20,9 & 113 & 43,8 & 78 & 30,2 & 258 & 100,0 \\
\hline 3 & I appreciate the performer for this campaign . & 8 & 3,2 & 13 & 5,1 & 33 & 13,0 & 100 & 39,5 & 99 & 39,1 & 253 & 100,0 \\
\hline 4 & $\begin{array}{l}\text { I want to contribute to this campaign through volunteery } \\
\text { work. }\end{array}$ & 10 & 4,0 & 26 & 10,3 & 46 & 18,2 & 98 & 38,7 & 73 & 28,9 & 253 & 100,0 \\
\hline 5 & I consider that the campaign is dealt with sufficiently & 9 & 3,5 & 35 & 13,7 & 100 & 39,2 & 77 & 30,2 & 34 & 13,3 & 255 & 100,0 \\
\hline 6 & $\begin{array}{l}\text { I consider that the subject of the campaign is relevant to } \\
\text { the field of the corporate. }\end{array}$ & 6 & 2,4 & 21 & 8,3 & 105 & 41,7 & 87 & 34,5 & 33 & 13,1 & 252 & 100,0 \\
\hline 7 & $\begin{array}{l}\text { I consider that the corporate serves the purpose of the } \\
\text { campaign. }\end{array}$ & 3 & 1,2 & 13 & 5,2 & 88 & 35,5 & 104 & 41,9 & 40 & 16,1 & 248 & 100,0 \\
\hline 8 & $\begin{array}{l}\text { I consider that the communication tools are effectively and } \\
\text { sufficiently used in the campaign. }\end{array}$ & 4 & 1,6 & 17 & 6,8 & 62 & 24,9 & 102 & 40,9 & 64 & 25,7 & 249 & 100,0 \\
\hline 9 & $\begin{array}{l}\text { I consider that the society is sufficiently informed about } \\
\text { the campaign . }\end{array}$ & 6 & 2,4 & 31 & 12,5 & 78 & 31,5 & 94 & 37,9 & 39 & 15,7 & 248 & 100,0 \\
\hline 10 & $\begin{array}{l}\text { I consider that the compaing works in a way to increase the } \\
\text { respect of the corporate in public eye. }\end{array}$ & 1 & 0,4 & 12 & 4,9 & 51 & 20,7 & 106 & 43,1 & 76 & 30,9 & 246 & 100,0 \\
\hline 11 & $\begin{array}{l}\text { I consider that the campaign contribute to the positive } \\
\text { image of the corporate. }\end{array}$ & 1 & 0,4 & 5 & 2,0 & 45 & 17,9 & 119 & 47,4 & 81 & 32,3 & 251 & 100,0 \\
\hline 12 & $\begin{array}{l}\text { I consider that the corporate behaves ethically in the } \\
\text { campaign related works. }\end{array}$ & 6 & 2,4 & 9 & 3,6 & 107 & 43,3 & 81 & 32,7 & 44 & 17,8 & 247 & 100,0 \\
\hline 13 & $\begin{array}{l}\text { I consider that the corporate should continue its campaign } \\
\text { related activities }\end{array}$ & 5 & 2,0 & 6 & 2,4 & 40 & 16,1 & 86 & 34,6 & 111 & 44,8 & 248 & 100,0 \\
\hline 14 & $\begin{array}{l}\text { I appreciate the corporate for its attempts in social } \\
\text { responsibilities. }\end{array}$ & 5 & 2,0 & 9 & 3,6 & 30 & 12,0 & 91 & 36,2 & 116 & 46,2 & 251 & 100,0 \\
\hline 15 & $\begin{array}{l}\text { The social responsibility attempts of the corporate are } \\
\text { affective in my decision making processes to buy. }\end{array}$ & 15 & 6,0 & 26 & 10,4 & 86 & 34,4 & 78 & 31,2 & 45 & 18,0 & 250 & 100,0 \\
\hline
\end{tabular}

The statements that the participants suggest that they strongly agree with are as follows: (Table 14):

The rate of those who suggest that they agree and strongly agree with the statement, "I consider that the campaign is beneficial to the society" is $87 \%$. 
The rate of those who suggest that they agree and strongly agree with the statement, "I consider that the corporate should continue its campaign related activities" is $77,2 \%$.

The rate of those who suggest that they agree and strongly agree with the statement, "I appreciate the corporate for its attempts in social responsibilities" is $80.7 \%$.

The statements that the participants suggest that they strongly disagree with are as follows.

The rate of those who suggest that they agree and strongly agree with the statement, "I would wish to work for this campaign as well" is $13 \%$.

The rate of those who suggest that they agree and strongly agree with the statement, "the social responsibility attempts of the corporate are affective in my decision making processes to buy" is $16.5 \%$.

The highest neutral rate is for the following statement "I consider that the corporate behaves ethically in its campaign related activities (\%45).

Table 14 Distribution of Opinion About The Campaigns

\begin{tabular}{|c|c|c|c|c|c|c|c|c|c|c|c|c|c|}
\hline & \multirow[t]{2}{*}{ Lets Go to School, Girls (Haydi Kızlar Okula) - HKO } & \multicolumn{2}{|c|}{$\begin{array}{l}\text { Strongly } \\
\text { Disagree }\end{array}$} & \multicolumn{2}{|c|}{ Disagree } & \multicolumn{2}{|c|}{ Neutral } & \multicolumn{2}{|c|}{ Agree } & \multicolumn{2}{|c|}{$\begin{array}{l}\text { Strongly } \\
\text { Agree }\end{array}$} & \multicolumn{2}{|c|}{ Total } \\
\hline & & $\begin{array}{c}\text { Fre } \\
.\end{array}$ & $\%$ & Fre. & $\%$ & Fre. & $\%$ & Fre. & $\%$ & Fre. & $\%$ & Fre. & $\%$ \\
\hline 1 & I consider that the campaign is very beneficial to the society. & 5 & 2,0 & 6 & 2,4 & 22 & 8,6 & 106 & 41,6 & 116 & 45,5 & 255 & 100,0 \\
\hline 2 & I consider that the compaing is of great success. & 5 & 2,0 & 13 & 5,1 & 54 & 21,3 & 110 & 43,5 & 71 & 28,1 & 253 & 100,0 \\
\hline 3 & I appreciate the performer for this campaign . & 11 & 4,5 & 10 & 4,0 & 41 & 16,6 & 92 & 37,2 & 93 & 37,7 & 247 & 100,0 \\
\hline 4 & $\begin{array}{l}\text { I want to contribute to this campaign through volunteery } \\
\text { work. }\end{array}$ & 12 & 4,9 & 20 & 8,2 & 50 & 20,4 & 93 & 38,0 & 70 & 28,6 & 245 & 100,0 \\
\hline 5 & I consider that the campaign is dealt with sufficiently & 6 & 2,4 & 31 & 12,4 & 95 & 38,0 & 89 & 35,6 & 29 & 11,6 & 250 & 100,0 \\
\hline 6 & $\begin{array}{l}\text { I consider that the subject of the campaign is relevant to the } \\
\text { field of the corporate. }\end{array}$ & 7 & 2,9 & 23 & 9,4 & 102 & 41,6 & 79 & 32,24 & 34 & 13,9 & 245 & 100,0 \\
\hline 7 & $\begin{array}{l}\text { I consider that the corporate serves the purpose of the } \\
\text { campaign. }\end{array}$ & 6 & 2,5 & 14 & 5,7 & 88 & 36,1 & 105 & 43,0 & 31 & 12,7 & 244 & 100,0 \\
\hline 8 & $\begin{array}{l}\text { I consider that the communication tools are effectively and } \\
\text { sufficiently used in the campaign. }\end{array}$ & 4 & 1,6 & 28 & 11,4 & 67 & 27,3 & 97 & 39,6 & 49 & 20,0 & 245 & 100,0 \\
\hline 9 & $\begin{array}{l}\text { I consider that the society is sufficiently informed about the } \\
\text { campaign. }\end{array}$ & 6 & 2,5 & 37 & 15,2 & 70 & 28,7 & 92 & 37,7 & 39 & 16,0 & 244 & 100,0 \\
\hline 10 & $\begin{array}{l}\text { I consider that the compaing works in a way to increase the } \\
\text { respect of the corporate in public eye. }\end{array}$ & 5 & 2,0 & 15 & 6,1 & 47 & 19,1 & 103 & 41,9 & 76 & 30,9 & 246 & 100,0 \\
\hline 11 & $\begin{array}{l}\text { I consider that the campaign contribute to the positive image } \\
\text { of the corporate. }\end{array}$ & 2 & $\mathbf{0 , 8}$ & 10 & 4,1 & 47 & 19,4 & 110 & 45,5 & 73 & 30,2 & 242 & 100,0 \\
\hline
\end{tabular}




\begin{tabular}{|c|c|c|c|c|c|c|c|c|c|c|c|c|c|}
\hline 12 & $\begin{array}{l}\text { I consider that the corporate behaves ethically in the } \\
\text { campaign related works. }\end{array}$ & 6 & 2,5 & 9 & 3,8 & 108 & 45,0 & 85 & 35,4 & 32 & 13,3 & 240 & 100,0 \\
\hline 13 & $\begin{array}{l}\text { I consider that the corporate should continue its campaign } \\
\text { related activities }\end{array}$ & 6 & 2,4 & 11 & 4,5 & 39 & 15,9 & 83 & $\mathbf{3 3 , 7}$ & 107 & 43,5 & 246 & 100,0 \\
\hline 14 & $\begin{array}{l}\text { I appreciate the corporate for its attempts in social } \\
\text { responsibilities. }\end{array}$ & 6 & 2,5 & 8 & 3,3 & 33 & 13,6 & 89 & 36,9 & 106 & 43,8 & 242 & 100,0 \\
\hline 15 & $\begin{array}{l}\text { The social responsibility attempts of the corporate are } \\
\text { affective in my decision making processes to buy. }\end{array}$ & 14 & 5,8 & 26 & 10,7 & 87 & 35,8 & 78 & 32,1 & 38 & 15,6 & 243 & 100,0 \\
\hline
\end{tabular}

The statements that the participants suggest that they strongly agree with are as follows: (Table 15):

The rate of those who suggest that they agree and strongly agree with the statement, "I consider that the corporate should continue its compaign related activities" is $67,9 \%$.

The rate of those who suggest that they agree and strongly agree with the statement, "I appreciate the corporate for its attempts in social responsibilities" is $73,3 \%$.

The statements that the participants suggest that they strongly disagree with are as follows.

The rate of those who suggest that they agree and strongly agree with the statement, "I consider that the society is sufficiently informed about the compaign" is $29,4 \%$.

The rate of those who suggest that they agree and strongly agree with the statement, "the social responsibility attempts of the corporate are affective in my decision making processes to buy" is $16.4 \%$.

The highest neutral rate is for the following statement "I consider that the corporate behaves ethically in its campaign related activities $(\% 43,3)$ and "I consider that the subject of the compaign is relevant to the field of the corporate" $(\% 56)$

Table 15 Distribution of Opinion About The Campaigns

\begin{tabular}{|c|c|c|c|c|c|c|c|c|c|c|c|c|c|}
\hline & \multirow[t]{2}{*}{ Stop Family Violence (Aile İçi Şiddet Son)-AISS } & \multicolumn{2}{|c|}{$\begin{array}{l}\text { Strongly } \\
\text { Disagree }\end{array}$} & \multicolumn{2}{|c|}{ Disagree } & \multicolumn{2}{|c|}{ Neutral } & \multicolumn{2}{|c|}{ Agree } & \multicolumn{2}{|c|}{$\begin{array}{c}\text { Strongly } \\
\text { Agree }\end{array}$} & \multicolumn{2}{|c|}{ Total } \\
\hline & & Fre. & $\%$ & Fre. & $\%$ & Fre. & $\%$ & Fre. & $\%$ & Fre. & $\%$ & Fre. & $\%$ \\
\hline 1 & I consider that the campaign is very beneficial to the society. & 7 & 2,8 & 17 & 6,8 & 72 & 28,8 & 74 & 29,6 & 80 & 32,0 & 250 & 100,0 \\
\hline 2 & I consider that the compaing is of great success. & 7 & 2,9 & 40 & 16,6 & 119 & 49,4 & 47 & 19,5 & 28 & 11,6 & 241 & 100,0 \\
\hline 3 & I appreciate the performer for this campaigr & 9 & 3,8 & 13 & 5,4 & 68 & 28,5 & 80 & 33,5 & 69 & 28,9 & 239 & 100,0 \\
\hline
\end{tabular}




\begin{tabular}{|c|c|c|c|c|c|c|c|c|c|c|c|c|c|}
\hline 4 & I want to contribute to this campaign through volunteery work. & 14 & 5,9 & 28 & 11,8 & 62 & 26,1 & 84 & 35,3 & 50 & 21,0 & 238 & 100,0 \\
\hline 5 & I consider that the campaign is dealt with sufficiently & 18 & $\mathbf{7 , 4}$ & 44 & 18,2 & 120 & 49,6 & 51 & 21,1 & 9 & 3,7 & 242 & 100,0 \\
\hline 6 & $\begin{array}{l}\text { I consider that the subject of the campaign is relevant to the } \\
\text { field of the corporate. }\end{array}$ & 4 & 1,7 & 23 & 9,7 & 134 & 56,3 & 62 & 26,1 & 15 & 6,3 & 238 & 100,0 \\
\hline 7 & I consider that the corporate serves the purpose of the campaign & 6 & 2,5 & 15 & 6,3 & 122 & 50,8 & 77 & 32,1 & 20 & 8,3 & 240 & 100,0 \\
\hline 8 & $\begin{array}{l}\text { I consider that the communication tools are effectively and } \\
\text { sufficiently used in the campaign. }\end{array}$ & 13 & 5,4 & 38 & 15,9 & 113 & 47,3 & 61 & 25,5 & 14 & 5,9 & 239 & 100,0 \\
\hline 9 & $\begin{array}{l}\text { I consider that the society is sufficiently informed about the } \\
\text { campaign. }\end{array}$ & 25 & 10,5 & 45 & 18,9 & 108 & 45,4 & 47 & 19,8 & 13 & 5,5 & 238 & 100,0 \\
\hline 10 & $\begin{array}{l}\text { I consider that the compaing works in a way to increase the } \\
\text { respect of the corporate in public eye. }\end{array}$ & 3 & 1,3 & 25 & 10,5 & 79 & 33,1 & 81 & 33,9 & 51 & 21,3 & 239 & 100,0 \\
\hline 11 & $\begin{array}{l}\text { I consider that the campaign contribute to the positive image of } \\
\text { the corporate. }\end{array}$ & 2 & 0,8 & 15 & 6,4 & 81 & 34,3 & 85 & 36,1 & 53 & 22,5 & 236 & 100,0 \\
\hline 12 & $\begin{array}{l}\text { I consider that the corporate behaves ethically in the campaign } \\
\text { related works. }\end{array}$ & 3 & 1,3 & 15 & 6,3 & 134 & 56,5 & 63 & 26,6 & 22 & 9,3 & 237 & 100,0 \\
\hline 13 & $\begin{array}{l}\text { I consider that the corporate should continue its campaign } \\
\text { related activities }\end{array}$ & 5 & 2,1 & 11 & 4,6 & 60 & 25,3 & 65 & 27,4 & 96 & 40,5 & 237 & 100,0 \\
\hline 14 & $\begin{array}{l}\text { I appreciate the corporate for its attempts in social } \\
\text { responsibilities. }\end{array}$ & 5 & 2,1 & 9 & 3,8 & 49 & 20,5 & 75 & 31,4 & 101 & 42,3 & 239 & 100,0 \\
\hline 15 & $\begin{array}{l}\text { The social responsibility attempts of the corporate are affective } \\
\text { in my decision making processes to buy. }\end{array}$ & 16 & 6,7 & 29 & 12,2 & 105 & 44,1 & 50 & 21,0 & 38 & 16,0 & 238 & 100,0 \\
\hline
\end{tabular}

The statements that the participants suggest that they strongly agree with are as follows: (Table 16):

The rate of those who suggest that they agree and strongly agree with the statement, "I consider that the corporate should continue its campaign related activities" is $68,4 \%$.

The rate of those who suggest that they agree and strongly agree with the statement, "I appreciate the corporate for its attempts in social responsibilities" is $74,7 \%$.

The statements that the participants suggest that they strongly disagree with are as follows. The rate of those who suggest that they are not agree and strongly not agree with the statement, "I consider that the society is sufficiently informed about the campaign" is $27,9 \%$. 
The rate of those who suggest that they agree and strongly agree with the statement, "the social responsibility attempts of the corporate are affective in my decision making processes to buy" is $17 \%$.

The highest neutral rate is for the following statement "I consider that the corporate behaves ethically in its campaign related activities","I consider that the campaign is dealt with sufficiently". "I consider that the subject of the campaign is relevant to the field of the corporate". "I consider that the corporate serves the purpose of the campaign" (\%50).

Table 16 Distribution of Opinion About The Campaigns

\begin{tabular}{|c|c|c|c|c|c|c|c|c|c|c|c|c|c|}
\hline & \multirow[t]{2}{*}{ Long Live Our School (Yasasin Okulumuz) - YO } & \multicolumn{2}{|c|}{$\begin{array}{l}\text { Strongly } \\
\text { Disagree }\end{array}$} & \multicolumn{2}{|c|}{ Disagree } & \multicolumn{2}{|c|}{ Neutral } & \multicolumn{2}{|c|}{ Agree } & \multicolumn{2}{|c|}{$\begin{array}{l}\text { Strongly } \\
\text { Agree }\end{array}$} & \multicolumn{2}{|c|}{ Total } \\
\hline & & Fre. & $\%$ & Fre. & $\%$ & Fre. & $\%$ & Fre. & $\%$ & Fre. & $\%$ & Fre. & $\%$ \\
\hline 1 & $\begin{array}{l}\text { I consider that the campaign is very beneficial to the } \\
\text { society. }\end{array}$ & 8 & 3,2 & 12 & 4,8 & 50 & 19,9 & 92 & 36,7 & 89 & 35,5 & 251 & 100,0 \\
\hline 2 & I consider that the compaing is of great success. & 8 & 3,3 & 23 & 9,4 & 92 & 37,6 & 81 & 33,1 & 41 & 16,7 & 245 & 100,0 \\
\hline 4 & $\begin{array}{l}\text { I want to contribute to this campaign through volunteery } \\
\text { work. }\end{array}$ & 12 & 4,9 & 23 & 9,4 & 69 & 28,3 & 83 & 34,0 & 57 & 23,4 & 244 & 100,0 \\
\hline 5 & I consider that the campaign is dealt with sufficiently & 14 & 5,7 & 42 & 17,0 & 127 & 51,4 & 47 & 19,0 & 17 & 6,9 & 247 & 100,0 \\
\hline 8 & $\begin{array}{l}\text { I consider that the communication tools are effectively and } \\
\text { sufficiently used in the campaign. }\end{array}$ & 10 & 4,1 & 33 & 13,6 & 105 & 43,4 & 64 & 26,4 & 30 & 12,4 & 242 & 100,0 \\
\hline 9 & $\begin{array}{l}\text { I consider that the society is sufficiently informed about the } \\
\text { campaign. }\end{array}$ & 19 & 7,9 & 41 & 17,0 & 96 & 39,8 & 62 & 25,7 & 23 & 9,5 & 241 & 100,0 \\
\hline 10 & $\begin{array}{l}\text { I consider that the compaing works in a way to increase the } \\
\text { respect of the corporate in public eye. }\end{array}$ & 4 & 1,7 & 16 & 6,7 & 88 & 36,7 & 81 & 33,8 & 51 & 21,3 & 240 & 100,0 \\
\hline 11 & $\begin{array}{l}\text { I consider that the campaign contribute to the positive } \\
\text { image of the corporate. }\end{array}$ & 6 & 2,5 & 11 & 4,6 & 76 & 31,5 & 88 & 36,5 & 60 & 24,9 & 241 & 100,0 \\
\hline
\end{tabular}




\begin{tabular}{|c|c|c|c|c|c|c|c|c|c|c|c|c|c|}
\hline 14 & $\begin{array}{l}\text { I appreciate the corporate for its attempts in social } \\
\text { responsibilities. }\end{array}$ & 8 & 3,3 & 10 & 4,1 & 43 & 17,8 & 82 & 34,0 & 98 & 40,7 & 241 & 100,0 \\
\hline 15 & $\begin{array}{l}\text { The social responsibility attempts of the corporate are } \\
\text { affective in my decision making processes to buy. }\end{array}$ & 20 & 8,3 & 21 & 8,7 & 103 & 42,6 & 65 & 26,9 & 33 & 13,6 & 242 & 100,0 \\
\hline
\end{tabular}

The statements that the participants suggest that they strongly agree with are as follows: (Table 17):

The rate of those who suggest that they agree and strongly agree with the statement, "I consider that the campaign is beneficial to the society" is $56,2 \%$.

The rate of those who suggest that they agree and strongly agree with the statement, "I consider that the corporate should continue its campaign related activities" is $59,4 \%$.

The rate of those who suggest that they agree and strongly agree with the statement, "I appreciate the corporate for its attempts in social responsibilities" is $66,8 \%$.

The statements that the participants suggest that they strongly disagree with are as "I consider that the society is sufficiently informed about the campaign" 39,4\%.

The rate of those who suggest that they agree and strongly agree with the statement, "t I consider that the communication tools are effectively and sufficiently used in the campaign" is $29,4 \%$.

The highest neutral rate is for the following statement "I consider that the corporate behaves ethically in its campaign related activities $(\% 62,8)$, "I consider that the compaing is of great success" $(54,2)$ "I consider that the campaign is dealt with sufficiently" (56,1\%), "I consider that the corporate serves the purpose of the campaign" (54,1\%) and "I consider that the subject of the campaign is relevant to the field of the corporate" $(59,1 \%)$.

Table 17 Distribution of Opinion About The Campaigns

\begin{tabular}{|c|c|c|c|c|c|c|c|c|c|c|c|c|c|}
\hline \multicolumn{2}{|r|}{$\begin{array}{c}\text { Standing United for Education (Ĕgitimde Gönül Birliği) } \\
\text { - EGB }\end{array}$} & \multicolumn{2}{|c|}{$\begin{array}{l}\text { Strongly } \\
\text { Disagree }\end{array}$} & \multicolumn{2}{|c|}{ Disagree } & \multicolumn{2}{|c|}{ Neutral } & \multicolumn{2}{|c|}{ Agree } & \multicolumn{2}{|c|}{$\begin{array}{c}\text { Strongly } \\
\text { Agree }\end{array}$} & \multicolumn{2}{|c|}{ Total } \\
\hline & & Fre. & $\%$ & Fre. & $\%$ & Fre. & $\%$ & Fre. & $\%$ & Fre. & $\%$ & Fre. & $\%$ \\
\hline 1 & $\begin{array}{l}\text { I consider that the campaign is very beneficial to the } \\
\text { society. }\end{array}$ & 8 & 3,3 & 12 & 5,0 & 86 & 35,5 & 72 & 29,8 & 64 & 26,4 & 242 & 100,0 \\
\hline 2 & I consider that the compaing is of great success. & 13 & 5,5 & 22 & 9,2 & 129 & $\mathbf{5 4 , 2}$ & 52 & 21,8 & 22 & 9,2 & 238 & 100,0 \\
\hline 3 & I appreciate the performer for this campaign . & 17 & 7,3 & 14 & 6,0 & 79 & 33,8 & 62 & 26,5 & 62 & 26,5 & 234 & 100,0 \\
\hline 4 & $\begin{array}{l}\text { I want to contribute to this campaign through } \\
\text { volunteery work. }\end{array}$ & 13 & 5,5 & 21 & 8,9 & 82 & 34,6 & 75 & 31,6 & 46 & 19,4 & 237 & 100,0 \\
\hline
\end{tabular}




\begin{tabular}{|c|c|c|c|c|c|c|c|c|c|c|c|c|c|}
\hline 5 & I consider that the campaign is dealt with sufficiently & 22 & 9,2 & 41 & 17,2 & 134 & \begin{tabular}{|l|l}
56,1 \\
\end{tabular} & 34 & 14,2 & 8 & 3,3 & 239 & 100,0 \\
\hline 6 & $\begin{array}{l}\text { I consider that the subject of the campaign is relevant } \\
\text { to the field of the corporate. }\end{array}$ & 12 & 5,2 & 21 & 9,1 & 137 & \begin{tabular}{|l}
59,1 \\
\end{tabular} & 46 & $\mid$\begin{tabular}{|l}
19,8 \\
\end{tabular} & 16 & 6,9 & 232 & 100,0 \\
\hline 7 & $\begin{array}{l}\text { I consider that the corporate serves the purpose of the } \\
\text { campaign. }\end{array}$ & 9 & 3,9 & 21 & 9,0 & 126 & 54,1 & 61 & 26,2 & 16 & 6,9 & 233 & 100,0 \\
\hline 8 & $\begin{array}{l}\text { I consider that the communication tools are effectively } \\
\text { and sufficiently used in the campaign. }\end{array}$ & 31 & 13,2 & 38 & 16,2 & 114 & 48,5 & 41 & 17,4 & 11 & 4,7 & 235 & 100,0 \\
\hline 9 & $\begin{array}{l}\text { I consider that the society is sufficiently informed about } \\
\text { the campaign . }\end{array}$ & 41 & 17,4 & 52 & 22,0 & 100 & 42,4 & 32 & 13,6 & 11 & 4,7 & 236 & 100,0 \\
\hline 10 & $\begin{array}{l}\text { I consider that the compaing works in a way to increase } \\
\text { the respect of the corporate in public eye. }\end{array}$ & 9 & 3,9 & 16 & 6,9 & 98 & 42,1 & 74 & 31,8 & 36 & 15,5 & 233 & 100,0 \\
\hline 11 & $\begin{array}{l}\text { I consider that the campaign contribute to the positive } \\
\text { image of the corporate. }\end{array}$ & 9 & 3,9 & 15 & 6,4 & 86 & 36,9 & 79 & 33,9 & 44 & 18,9 & 233 & 100,0 \\
\hline 12 & $\begin{array}{l}\text { I consider that the corporate behaves ethically in the } \\
\text { campaign related works. }\end{array}$ & 10 & 4,3 & 13 & 5,6 & 145 & 62,8 & 46 & 19,9 & 17 & 7,4 & 231 & 100,0 \\
\hline 13 & $\begin{array}{l}\text { I consider that the corporate should continue its } \\
\text { campaign related activities }\end{array}$ & 14 & 6,0 & 11 & 4,7 & 70 & 29,9 & 58 & 24,8 & 81 & 34,6 & 234 & 100,0 \\
\hline 14 & $\begin{array}{l}\text { I appreciate the corporate for its attempts in social } \\
\text { responsibilities. }\end{array}$ & 9 & 3,8 & 12 & 5,1 & 57 & 24,3 & 74 & $\mathbf{3 1 , 5}$ & 83 & 35,3 & 235 & 100,0 \\
\hline 15 & $\begin{array}{l}\text { The social responsibility attempts of the corporate are } \\
\text { affective in my decision making processes to buy. }\end{array}$ & 23 & 9,7 & 25 & 10,5 & 111 & 46,8 & 46 & 19,4 & 32 & 13,5 & 237 & 100,0 \\
\hline
\end{tabular}

\section{Conclusion}

The present study aims to reveal to what extend the campaigns listed as the top five campaigns in by the students from the faculty of Communication are successful in Turkey in terms of communication studies and their reputations. Whereas only four of these five campaigns are directed to different purposes, only one of them is against violence. Education was found to be the most prior issue in Turkey in the eyes of the participants. The fact that the students' points of view related to the priorities of the problems in Turkey are in parallel with the campaigns chosen demonstrates that they follow the agenda of the country. When the students were asked to write the names of the campaigns which they consider as being very important for the country, it is observed that two of the abovementioned campaigns are placed in their lists. The list that students prepared also includes four education-related campaigns and one campaign against smoking. 
The responses received from the participants suggest the following conclusions related to the abovementioned five campaigns and the aids to make them remember the communication studies:

- students generally do not have difficulty in recalling logos and TV commercials. Besides, most of the students remember hearing people talk about this issue.

- majority of the participants suggest that they did not participate in any activities of the campaign and did not contribute to it.

- majority of the responses suggest that students did not read radio spot and magazine articles and did not visit the web pages.

Considering these analysis and evaluations, it is possible to draw the following conclusions.

- logos and TV commercials are considered as very important. Therefore, much attention should be paid to the design of both so as to reach the target group.

- There are two major causes of the attitudes towards radio spots and newspaper articles; the first is the lack of radio sports and newspaper articles and the latter is that students do not pay enough attention to these communication means.

Both of these cases are considered as the deficiency for the campaign s. More studies should be carried out to be able to them more effectively.

- The web pages should be advertised better and they should be prepared more attractive for people.

The obtained data from the students about the corporations and organizations which lead the campaigns suggests the following conclusions:

- Great majority of the students who took the questionnaire state that the campaign is very beneficial for the society, that the campaign should continue and that the campaigns helped the corporations increase their reputations and gain a positive image.

- It was found that the participants seemed reluctant about the following statements; working for the campaigns, the effectiveness of the practices in their decision making procedures in purchasing. 
- The issues about which the participants were found to be indecisive are whether the corporations and organizations behave ethical in the campaign related activities that the chosen campaign subject matches with the operational field of the corporate.

As the rate of recalling decreases, the responses of the participants were found to be more indecisive and it was found that they considered the corporations insufficient with regards to communication activities. The most surprising finding of this study is that students do not want to work for the campaigns because they think that they will be involved in such activities after they graduate from their departments. Therefore, students' awareness needs to be raised. This study is a descriptive one. The future studies in this field will investigate what types of works students will choose at their departments for a better and more effective campaign. 


\section{References}

Babacan, Muazzez (2005) Reklamcılık: Temel Kavramlar (Advertising: Basic Concepts), Detay Yayınc1lik: Ankara

Bayıksel, S.O. (2010) " Kurumsal Sosyal Sorumluluk Araştırması” Capital Türkiye Dergisi Mart sayıs1: http:/www.capital.com.tr/haber.aspx?HBR_KOD=5871

Kadıbesegil, S. (2006) Itibar Yönetimi (Repuation Management), Mediacat Yayınları: Istanbul Rogers, Everett, Douglas Storey (1987) "Communication Campaigns" Editors: Charles Berger, Steven Chaffee, Handbook of Communication Science, Sage Publications, London.

Turkey Corporate Social Responsibility Baseline Report (2008) www.undp.org.tr/publicationsDocuments/CSR_Report_en.pdf

Web pages of campaigns

Baba Beni Okula Gönder (Father, Send me to School): http://www.bbog.org/index.html Haydi Kızlar Okula (Lets Go to School, Girls) : http://haydikizlarokula.meb.gov.tr Aile İçi Şiddet Son (Stop Family Violence) : http://www.aileicisiddeteson.com//default.aspx Yasasin Okulumuz (Long Live Our School): http://www.tocev.org.tr/english.html Eğitimde Gönül Birliği (Standing United for Education): http://www.egitimdegonulbirligi.org/ust.aspx?uid=6 